\title{
The Problems and Opinions of School Administrators during COVID-19 Pandemic: A Qualitative Study from Turkey
}

\author{
Assoc. Prof. Dr. Tufan Aytaç \\ Kırşehir Ahi Evran University, Turkey
}

Doi:10.19044/ejes.v7no4a5 URL:http://dx.doi.org/10.19044/ejes.v7no4a5

\begin{abstract}
The paper aims to describe the problems faced by some school administrators during COVID-19 pandemic in different cities and to present their opinions regarding the process. As one of the qualitative research methods, phenomenology pattern was used in the research. Data of the study were collected by using the interview technique through semi-structured School Administrators Interview Form. The study group consists of 32 school administrators selected by using purposeful criterion sampling technique. As a result of the research, it is observed that school administrators evaluate the application of Education Information Network (EBA) TV and education portal, which was put into practice by the Ministry of National Education (MoNE) due to COVID-19 pandemic, as a positive and urgent measure. School administrators expressed that the most common problems faced during COVID-19 pandemic are low learning motivation of students, parents' inability to create a learning environment at home, and the lack of access to live broadcasts from the EBA TV/education portal. The majority of school administrators observed that teachers were reluctant to teach in live lectures using the EBA education portal or other programs for various reasons and their motivation gradually decreased in the process. It is observed that half of the school administrators did not have an emergency action plan regarding the pandemic process, and they followed the instructions given by MoNE. School administrators stated that skills of technology leadership and crisis management are important requirements during the pandemic process.
\end{abstract}

Keywords: Education administration, coronavirus (COVID-19), pandemic, education, school. 


\section{Introduction}

COVID-19 pandemic has affected the education system as it has affected all other areas of life in the world and in Turkey. COVID-19 pandemic has not only affected children's lives but have also affected education and learning-teaching environments and methods. In Turkey, as schools were closed, the education process was interrupted and the children have started education at home. The pandemic has interrupted children's normal school-centered education, but this does not mean that it will stop their learning-teaching process. Described as the new normal in the world, COVID19 pandemic has affected the education and teaching processes and brought along many problems.

Most countries around the world have temporarily closed educational institutions to control the spread of COVID-19 pandemic. With the outbreak of COVID-19 pandemic in December 2019, 107 countries closed schools as of March 18, 2020. More than $90 \%$ of the student population in the world have been affected by the closure of schools. In Turkey, the number of students affected by this situation is 24,901,925 (UNESCO, 2020). While the health of students and the whole society is important in this process in which schools are closed, ensuring the continuity of the education-teaching process has also become important. In this context, many countries and Turkey have been implementing various alternative strategies and practices in order to continue education without interruption. An interesting research finding on this subject is the meta-synthesis study by Viner et al. (2020). In this study, it was stated that in COVID-19's latest modeling studies, the closure of schools prevented only $2-4 \%$ of deaths (much less than other social distance preventive measures). Due to COVID-19 pandemic, countries have temporarily interrupted their education and have continued their education with distance education applications (OECD, 2020; Tria, 2020; Ustun \& Özçiftçi, 2020, p.147; Yamamoto \& Altun, 2020, p.32). COVID-19 pandemic has brought extraordinary challenges and have affected the school community members (students, teachers, parents, administrators, etc.) (Tria, 2020). Thus, the most significant effect of COVID-19 pandemic is the stopping of face-to-face teaching in schools and moving to distance education methods.

In Turkey, the Ministry of Education (MoNE) closed schools all around the country on 16 March 2020 and it has continued distance education since then (EBA TV/portal and other applications). During the pandemic, distance education process in Turkey has continued through the Education Information Network (EBA) and EBA TV which are national distance education platforms (Özer, 2020; TEDMEM, 2020a). In this process, private schools have continued their education by using various distance education programs within their own means. 
Therefore, this study determining the effects of COVID-19 pandemic on the education period from the perspective of school administrators is one of the first studies carried out in order to reveal the situation of education in Turkey during the pandemic. It can be predicted that such studies shall be a source for studies related to the effects of COVID-19 pandemic on education and what can be done after this period. Revealing the opinions of school administrators and problems faced by them, who are one of the most important actors of the education process, regarding COVID-19 pandemic period will provide important data on how to establish the education system in the new normal order.

In education, as the 'New Normal' in the post-COVID-19 period, there is a need to consider education and learning systems in the light of emerging opportunities and challenges (Cahapay, 2020). In the educational context, in order to provide and sustain quality education despite the pandemic, the 'new normal educational policy' should be taken into consideration by the MoNE. In this context, this paper focuses on revealing the opinions of school administrators and the problems they are faced with in the education-teaching process while COVID-19 pandemic is still going on.

\section{Purpose of the Study}

This study aims to analyze the opinions of school administrators and the problems they are faced with in the education-teaching process while COVID-19 pandemic is still going on. Within this scope, this study aims to address the following research questions:

1. What are the opinions of school administrators regarding the effects of COVID-19 pandemic on education?

2. What are the problems faced by school administrators in the educationteaching process while COVID-19 pandemic is still going on?

\section{Method}

\section{Research Design}

As one of the qualitative research methods, phenomenology model was used in this research. The purpose of phenomenology studies is to reveal personal opinions and experiences related to a phenomenon at a more general level (Creswell, 2013, 2017; Marshall \& Rossman, 2014).

\section{Research Participants}

Participants of this study were determined through criterion sampling method which is one of the purposeful sampling methods (Creswell, 2013, 2017; Tashakkori \& Teddlie, 2010). Being a school administrator is taken as the main criterion while determining the participants. Study group of the research consists of 32 school administrators who work in public and private 
educational institutions in different cities of Turkey in 2019-2020 academic year. Information about the school administrators participating in the study is given in Table 1.

Table 1. Personal Information Regarding the Study Group

\begin{tabular}{lc}
\hline Gender & Number \\
\hline Male & 20 \\
Female & 12 \\
\hline Title & Number \\
\hline Headmaster & 20 \\
Deputy Head of School & 12 \\
\hline Professional Seniority & \\
\hline $0-5$ years & 3 \\
$6-10$ years & 4 \\
$11-15$ years & 6 \\
$16-20$ years & 12 \\
21 years and over & 7 \\
\hline Level of Education & \\
\hline Preschool & 7 \\
Primary Education & 10 \\
Secondary Education & 11 \\
Special Education & 4 \\
\hline Type of School & \\
\hline Public & 19 \\
Private & 13 \\
\hline
\end{tabular}

\section{Data Collection Process}

Interview technique was used as the data collection tool in the study. Data collection tool was created as semi-structured interview form considering the effects of COVID-19 pandemic on education. Data of the study was collected by using the interview technique via semi-structured School Administrator Interview Form. School Administrator Interview Form (SAIF) consists of three sections as being statement, personal information form, and the question form regarding the dimension of the effects of COVID-19 pandemic on education. Data of the study was collected from 32 school administrators through interview method on a voluntary basis. Each interview lasted for approximately 30 minute and all interviews were completed in one and a half months.

Some of the interviews were carried out through mutual synchronous interview by using Educational Project Based on Ahi Proficiency platform (EPBAP-AYDEP) and zoom programs; during this process, detailed written 
notes were taken. Additionally, in some sections of the study, the interview was sent to the school administrators according to the selection criteria (by turning the form into Google survey form program) and their answers were received and evaluated.

\section{Validity and Reliability}

Interview questions consist of six open-ended questions which are consistent with the aims of the study. SAIF was prepared. It was given attention because research questions have appropriate content and comprehensibility in the context of the effects of COVID-19 pandemic on education. Expert opinions ( 1 expert on educational management, 1 expert on qualitative research, and two school administrators) were received to ensure the comprehensibility and clarity of the dimensions and questions.

In the content analysis process, the consensus percentage formula of Miles and Huberman (1994) was used. Through this way, the consistency between the codes and themes determined by the researcher and two other independent experts were determined. Two other independent experts are two faculty members working in the field of educational management and educational psychology.

$$
\text { Consensus Percent }=\frac{\text { Consensus }}{\text { Consensus }+ \text { Divergence }} \times 100
$$

In this study, consensus rate between coders was calculated as .94 for the 1 st question, .91 for the 2 nd question, .91 for the 3 rd question, .96 for the 4th question, .92 for the 5 th question, and .95 for the 6th question. The interrater reliability score for the data analysis of the school administrators' interview was over .90 and this was sufficient (over .80 level) for the reliability of the coding according to Miles and Huberman (1994). According to Miles and Huberman (1994), if 80\% and more researcher and expert consensus are provided in a qualitative research, coding study will be considered to be reliable. In this respect, it can be said that the study is generally a reliable study.

\section{Data Analysis}

The data obtained from the interviews with school administrators were analyzed after their consents were obtained. The data were coded in the context of the aim of the research and dimensions. Created codes were transformed into themes/categories to reveal the research findings. Summarized and interpreted through the descriptive analysis, data were discussed in detail based on the content analysis (Bilgin, 2006; Y1ldirım \& 
Simsek, 2018). In the study, headmasters were coded as (H) and deputy heads of school were coded as (DH) and by a given number.

\section{Findings}

The themes and codes created in line with the opinions of school administrators are given below as dimensions (Figure 1 and Figure 2).

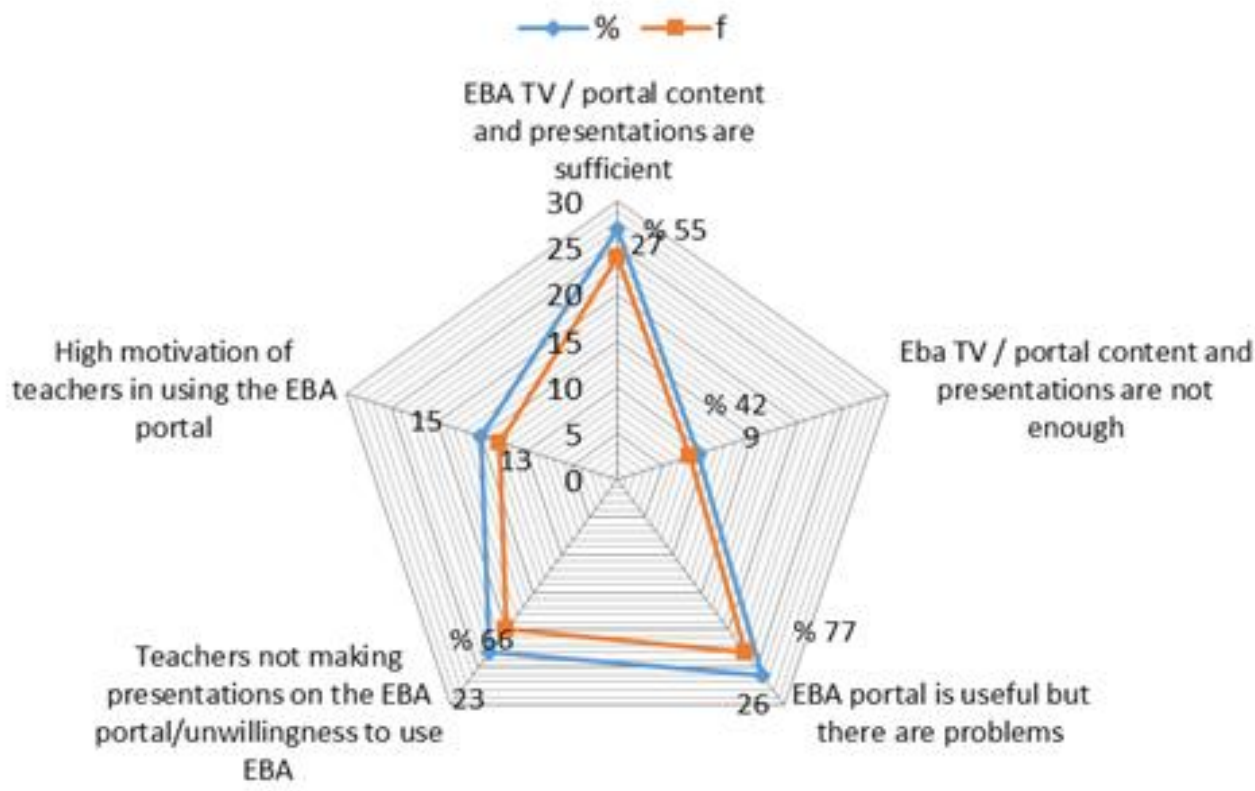

Figure 1. Thematic fields related to the use of EBA TV/education portal during COVID-19 pandemic

Considering the opinions and themes that stand out in the context of school administrators' opinions, it is observed that while EBA TV/education portal is considered positive, there are still some problems with the content, presentation, and connection. It is also stated that some teachers do not make presentations through EBA portal and they are reluctant to do so (Figure 1). 


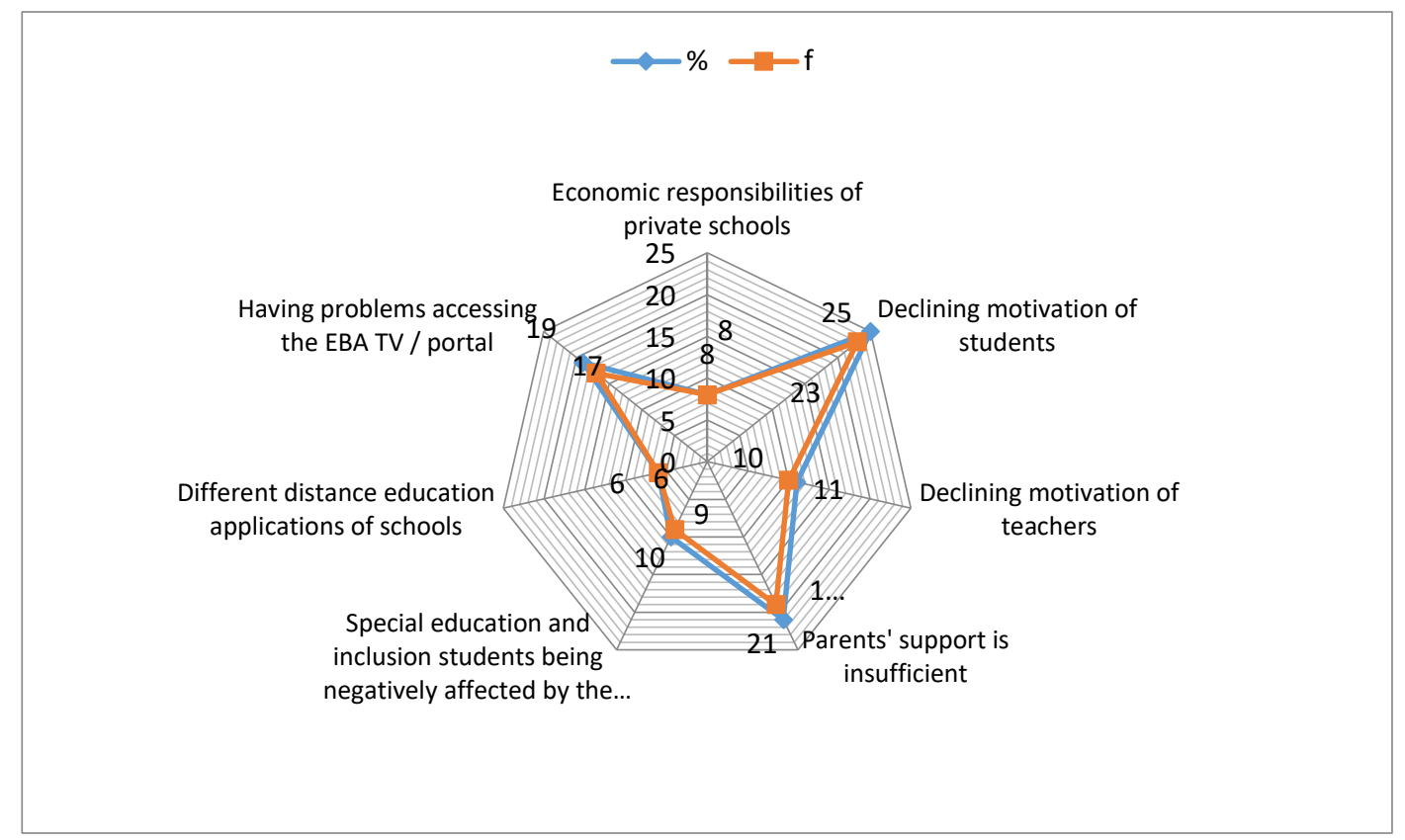

Figure 2. Problem areas faced by school administrators during COVID-19 pandemic

School administrators stated that students' learning motivation decreased, that parents could not provide the necessary comfort and support for students at home, and that students had problems with accessing EBATV/portal (Figure 2).

\section{Opinions of School Administrators on the Effects of COVID-19 Pandemic} on the Educational Process

Opinions of school administrators on the effects of COVID-19 pandemic on educational process are given in Table 2 as themes/categories. 
Table 2. What school administrators do in the context of the continuity of education during COVID-19 pandemic

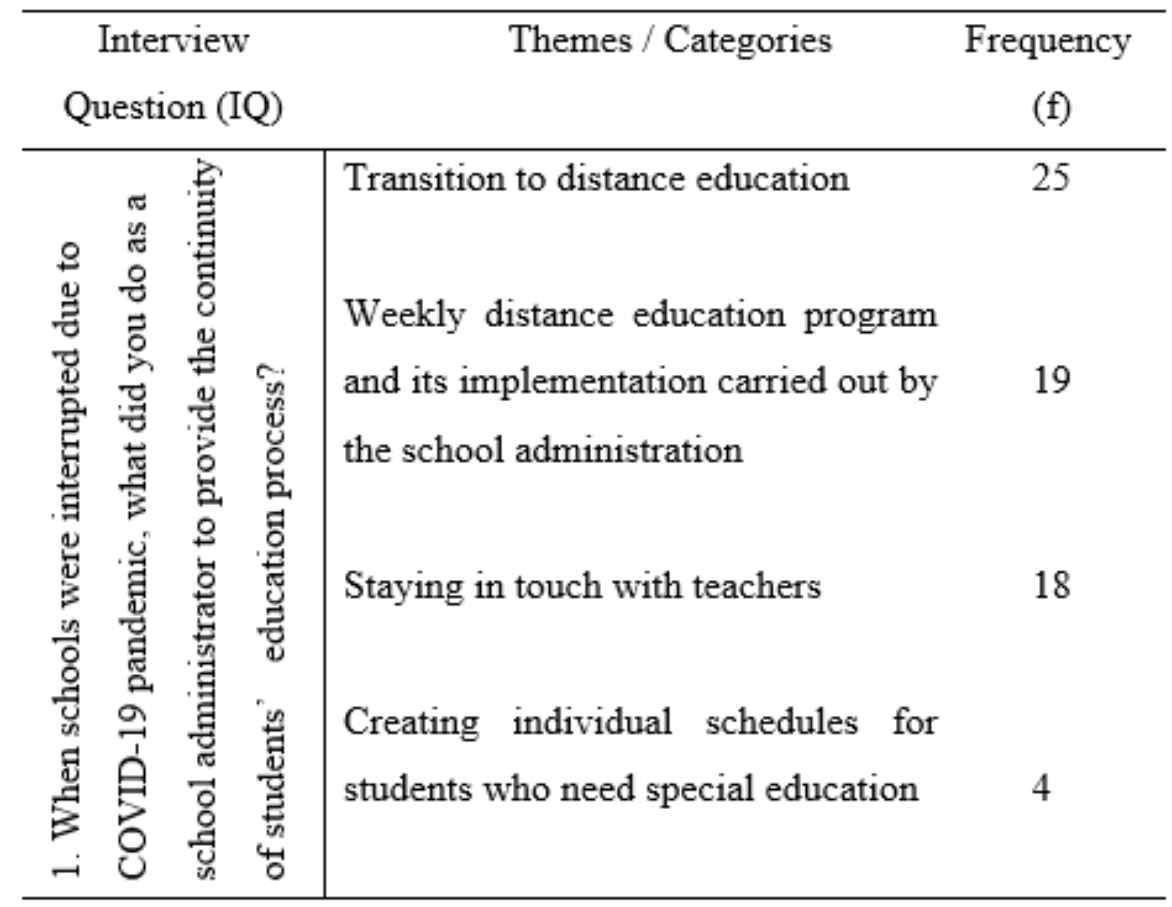

Opinions of school administrators regarding the break on education due to COVID-19 pandemic are collected under the following themes: "Transition to distance education" ( $\mathrm{f}=25)$, "Weekly distance education program and its implementation" ( $\mathrm{f}=19)$, "Staying in touch with teachers" $(\mathrm{f}=18)$, and "Creating individual schedules (for special education students)" $(f=4)$ (Table 2). Examples of opinions under this theme are given below: follows:

A high school headmaster working in a private school stated as

"Distance education video lectures and live lessons were implemented. We created weekly distance education schedules by using our own infrastructure, we sent them to teachers and parents, we followed it." (H2)

However, the majority of the students without internet connection and computer facilities could not receive distance education through EBA. School administrators suggested that teachers and students should watch and follow the subjects on EBA TV. 
School administrators working in private education institutions stated that they experienced some difficulties during the onset and continuation of COVID-19 pandemic. A deputy head of school working in a private school stated as follows:

"Since we have students with special needs, each has individual education plans. Weekly programs were prepared for our students with mild and moderate disabilities who are able to study with their parents." (DH12)

According to the findings, it is observed that the education process was continued by using EBA infrastructure after the school was interrupted by the Ministry of National Education due to COVID-19 pandemic.

Opinions of school administrators regarding the contents and presentations in EBA TV/education portal are given in Table 3 as themes/categories.

Table 3. Opinions of school administrators regarding the contents and presentations in EBA TV and education portal

\begin{tabular}{|c|c|c|}
\hline IQ & Themes / Categories & $F$ \\
\hline 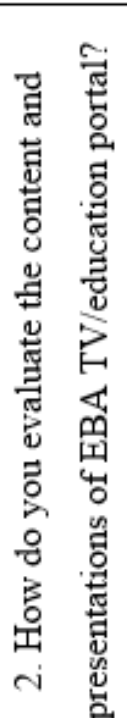 & $\begin{array}{l}\text { Contents and presentations of EBA TV/education } \\
\text { portal are effective and useful } \\
\text { EBA education portal is useful but there are some } \\
\text { problems } \\
\text { The content is not sufficient } \\
\text { Late additions of contents and activities for } \\
\text { preschool education level in EBA, and their } \\
\text { inadequateness }\end{array}$ & 23 \\
\hline
\end{tabular}

Opinions of school administrators regarding the contents and presentations in EBA TV/education portal are classified in the following themes: "EBA education portal is useful but there are some problems" ( $\mathrm{f}=23)$, "Contents and presentations of EBA TV/education portal are sufficient" $(\mathrm{f}=18)$, "Contents are not sufficient" $(\mathrm{f}=6)$, and "Lack and inadequateness of 
contents and activities for preschool education level in EBA" $(\mathrm{f}=6)$. Examples of opinions under this theme are given below:

An elementary school headmaster and a high school deputy head of school who are working in public schools stated as follows:

"I generally consider EBA TV and training portal effective in this process, but there may be problems in practice. Distance education conducted by EBA TV and TRT in coordination with the MoNE is more effective in the social isolation of our students." (H5).

"In the feedback we receive from the parents, it is seen that $90 \%$ of our students follow the lessons on EBA TV and $10 \%$ of them follow the online education." (DH31).

Although EBA TV/education portal is generally considered as a positive education platform, it cannot be effectively utilized due to reasons such as the duration of live lessons at EBA is less, the subjects are taught quickly, the monitoring/follow-up rates are low, teachers are not willing to use it, contents cannot be used in preparing for exams, and not all students have access to internet or computer. A public school administrator stated as follows:

"I think EBA is a very good platform. The country's competent teachers and the knowledge of the ministry are reflected there. There are two prominent problems in EBA: a) The technical infrastructure which is sufficient for the whole country could not be established immediately. b) Applicability and sustainability are difficult without follow-up and coordination in education. Monitoring is also low when watching EBA, which is only at the discretion of the student. Although we create weekly schedules, some teachers make excuses and do not teach even for 1 hour in a week, and then parents call me. I observe such reluctance among half of the teachers." (DH32)

According to the findings, school administrators stated that although EBA TV and education portal, which were put into practice by the MoNE due to COVID-19 pandemic, were positive and useful as an emergency measure, there are some problems such as technical problems in live broadcasts, low hours of lessons in weekly schedules, reluctance of teachers for distance education, and inefficacy of teachers in monitoring students and giving feedback. In this scope, it can be seen that education cannot be provided through this way for a long time during the COVID-19 pandemic.

Opinions of school administrators regarding teachers' attendance and motivation for live lesson education are given in Table 4 as themes/categories. 
Table 4. Opinions of school administrators regarding teachers' use of EBA or other programs and their motivation

\begin{tabular}{|c|c|c|c|c|c|}
\hline \multicolumn{3}{|c|}{ IQ } & \multicolumn{2}{|r|}{ Themes / Categories } & $\mathrm{F}$ \\
\hline 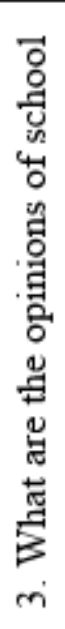 & 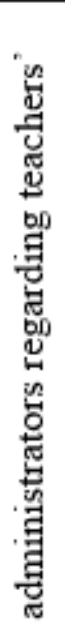 & 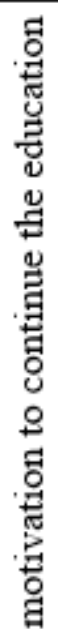 & 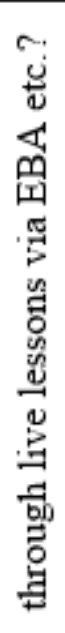 & $\begin{array}{l}\text { Motivation levels of teachers are low } \\
\text { and they are reluctant to have live } \\
\text { lessons }\end{array}$ & 15 \\
\hline
\end{tabular}

Opinions of school administrators are classified in the following themes: "Teachers continue live lessons and their motivation is high" ( $\mathrm{f}=13)$, "Motivation levels of teachers are low and they are reluctant to have live lessons" (f=15), "No live lessons" ( $\mathrm{f}=4$ ) (Table 4). Live lessons are carried out by using EBA education portal and other platforms; however, the example regarding the decrease in the motivation of teachers during COVID-19 pandemic is given as follow:

"Very limited number of teachers teach in live lessons through different applications. Competency and motivation of many teachers to teach in live lessons are very low." (DH28)

According to the findings, the majority of school administrators think that teachers' activities of conducting live lessons using EBA education portal or other programs have decreased and their motivation has gradually decreased. However, in this process, it is seen that there are devoted teachers who apply weekly course schedules and use the distance education system effectively.

Opinions of school administrators on the problems they faced in education and management within the scope of COVID-19 pandemic are given in Table 5 as themes/categories. 
Table 5. Problems Faced by School Administrators in the Education Process within the Scope of COVID-19 Pandemic

\begin{tabular}{|c|c|c|c|}
\hline & IQ & Themes / Categories & $\mathrm{F}$ \\
\hline 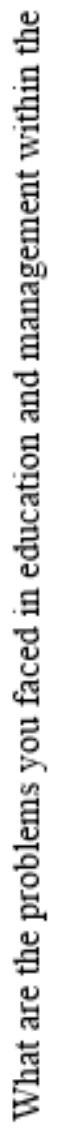 & 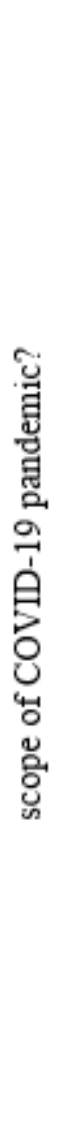 & $\begin{array}{l}\text { Technical connection problems in EBA education } \\
\text { portal during live classes and no computer/internet } \\
\text { (limited internet quota) } \\
\text { Different applications used by schools } \\
\text { No distance education suppert for inclusive and } \\
\text { disabled students who need special education } \\
\text { Family concerns and inadequate parental support } \\
\text { Having financial difficulties as a private school } \\
\text { Decreasing motivation of teachers and their } \\
\text { reluctance to make weekly schedules and to teach in } \\
\text { live lessons, lack of communication between } \\
\text { teachers }\end{array}$ & 10 \\
\hline$\dot{\theta}$ & & Decreasing motivation of students & 23 \\
\hline
\end{tabular}

School administrators pointed out the low motivation of students as the problem area they encountered most $(\mathrm{f}=23)$ (Table 5). A high school deputy head of school stated the following which supports this argument:

"According to the feedback I received from teachers, students do not watch EBA TV much. Students' participation in live broadcasts in EBA is good. But the student has gradually started forgetting and missing the school teachers, and we can hardly monitor students' learning progress and performance. The seniors have already left everything." (DH18)

The second important problem area stated by the school administrators during the COVID-19 pandemic is that parents could not provide sufficient 
support to their children at home, they could not create a learning environment at home, and could not motivate students $(\mathrm{f}=19)$. A high school headmaster stated the following which supports this argument:

"Parents do not know how to spend time with their children and they cannot motivate their children enough." (H5)

School administrators evaluated the fact that some of the students did not have the necessary computer and internet facilities to continue synchronous/asynchronous education from both EBA and other platforms during the COVID-19 pandemic as a problem area of third importance $(f=17)$. During this process, the limited internet quota of students and not having a computer, or having problems in sharing the computer at home, also negatively affected teachers' communication with students. In a sense, this has raised digital inequality. It can be said that during the pandemic, education does not progress well in terms of disadvantaged regions and families.

School administrators identified the lack of inclusion and distance education support for disabled students who are in need of special education as another problem area $(\mathrm{f}=9)$ during COVID-19 pandemic. School administrators state that during this process, these students can start their old negative habits again and the learning-behaviour differences between them and other students may increase. A private school administrator stated as follows:

"Since our inclusive students cannot receive educational support during this process, the difference with their peers is gradually increasing, and it will become noticeable when face-to-face education begins." (H25)

School administrators considered the decrease in the motivation of teachers as a problem area $(\mathrm{f}=10)$. School administrators express that teachers, especially those working in public schools, are unwilling to prepare and comply with live distance education curricula.

Private school administrators stated that they experienced economic problems during this process $(\mathrm{f}=8)$. A private high school deputy head of school also stated as follows:

"As a private school administrator, we have economic responsibilities. We have to calculate balances such as collection-payment and have to fulfill our responsibility to our employees." (H13)

According to the findings, the most common problems faced by school administrators during COVID-19 pandemic can be listed as failure to maintain motivation of students to learn, inability of parents to create a home learning environment for students, students' lack of access to live broadcasts, and connection problems of EBA education portal.

Opinions of school administrators regarding the risk/crisis management during COVID-19 pandemic are given in Table 6 as themes/categories. 
Table 6. Opinions of school administrators regarding the risk/crisis management during COVID-19 pandemic

\begin{tabular}{|c|c|c|c|c|}
\hline IC & & & Themes / Categories & f \\
\hline 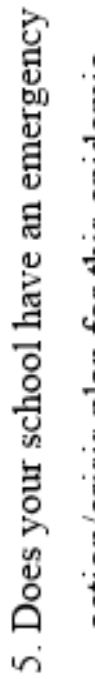 & & 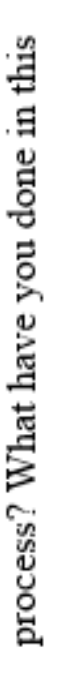 & $\begin{array}{l}\text { Preparing and implementing an emergency } \\
\text { action plan for COVID-19 outbreak } \\
\text { Carrying out works related to hygiene } \\
\text { (disinfecting the school, using hand sanitizers, } \\
\text { hanging leaflets about the virus) }\end{array}$ & 18 \\
\hline
\end{tabular}

School administrators stated that they made and implemented emergency action plans during the COVID-19 pandemic ( $\mathrm{f}=18$ ) (Table 6). It can be seen that with the interruption of schools following the outbreak, distance education plans were made and an action plan was created by holding meetings about the steps to be followed.

According to the findings, it is observed that half of the school administrators prepared and implemented an emergency action plan when they faced the COVID-19 pandemic. In particular, it is stated that distance education programs related to the practice of live lessons in EBA were urgently put into use and practices for ensuring hygiene were carried out quickly. A significant portion of the school administrators stated that they did not have an emergency action plan for this because they encountered such a pandemic for the first time, and that they mostly followed the instructions from the Ministry of National Education.

Opinions of school administrators regarding the education management process during the COVID-19 pandemic are given in Table 7 as themes/categories. 
Table 7. Opinions of school administrators regarding the education management process during the COVID-19 pandemic

\begin{tabular}{|c|c|c|c|}
\hline & IQ & Themes / Categories & $\mathrm{f}$ \\
\hline 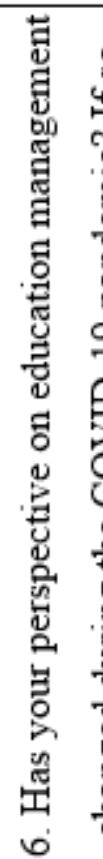 & 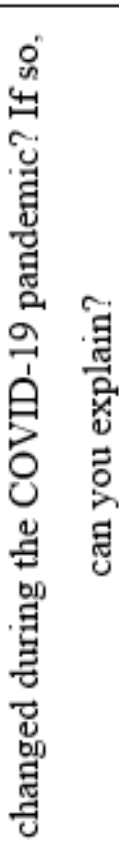 & $\begin{array}{l}\text { Being not ready for the distance education process } \\
\text { and realizing the importance of face-to-face } \\
\text { education and teaching } \\
\text { Necessity to improve crisis management skills } \\
\text { Paying attention to hygiene in daily life and in } \\
\text { school } \\
\text { As private schools, the importance of organizing } \\
\text { the process well and establishing a financial } \\
\text { balance (income-expense, debt balance) } \\
\text { Seeing the impact of technology and digitalization } \\
\text { in the education process, bringing digital and } \\
\text { technology leadership skills to the forefront }\end{array}$ & 14 \\
\hline
\end{tabular}

When considering their opinions on the education management process in the context of the COVID-19 pandemic, school administrators stated that they are not ready for the distance education process. They further stated that face-to-face education/teaching is important $(\mathrm{f}=20)$ (Table 7). Some school administrators supporting this opinion stated as follows:

"EBA needs to be improved. The importance of interaction in education has emerged, on the other hand, we have seen the effects of technological development on education. We saw that robots can be doctors, but robots cannot be teachers." (DH7)

School administrators stated that an awareness should be developed about giving importance to hygiene and making emergency action plans after the pandemic process $(\mathrm{f}=14)$. School administrators stated that emergency action plans in the context of occupational health and safety in schools should be updated, and issues such as protection and fight against pandemics such as COVID-19, hygiene education, etc. should be added to occupational health and safety trainings. Thus, a school administrator stated the following: 
"As the school administration, we understood that it is necessary to take precautions by considering the compelling situations to be emerged beforehand." (H2)

School administrators particularly emphasized the need for developing technology leadership skills $(\mathrm{f}=8)$ and crisis management ( $\mathrm{f}=10)$ skills. A school administrator supporting the opinion stated as follows:

"Technology now has a very important place in our lives. And leadership types such as digital leadership and information technology leadership have also entered in our lives, and school leaders should definitely be educated on this subject." (H29)

Private school administrators stated that it is important to establish a financing balance (income-expenditure, debt balance) $(\mathrm{f}=8)$ during the pandemic process. A school administrator supporting the opinion stated as follows:

"From the perspective of private school financing, we once again saw the advantage of progressing in a controlled way and the importance of balance in borrowing. Unfortunately, it is not possible for institutions with a high debt burden to survive in this process. The harmony of the teaching staff is also very important." (H30)

According to the findings, more than half of the school administrators stated that the distance education process via EBA could not be carried out properly in ensuring the continuity of education during the pandemic process. By expressing that the importance of face-to-face education and teachers is recognized once more, the place of school and classroom education in the learning process has been recognized again. School administrators stated that more emphasis should be placed on hygiene after the pandemic within the scope of occupational health and safety and that they should be included in the issues related to what to do against the epidemic while making emergency action plans. School administrators have the opinion that technology leadership and crisis management are important needs in the pandemic process and their competencies should be developed in these matters. Private school administrators stated that it is important to establish a financing balance (income-expense, debt balance) during the pandemic process, and that many private schools face the risk of closing down and not paying teachers' wages during this process. 


\section{Conclusion}

In this study, it is observed that school administrators evaluated the application of EBA TV and education portal, which was put into practice by the MoNE due to COVID-19 pandemic, as a positive and urgent measure. In this study, more than half of the school administrators stated that in ensuring the continuity of education during the pandemic process, distance education process via EBA could not be carried out properly. School administrators stated that they encountered problems in terms of infrastructure, access, and pedagogical issues in the process of teaching lessons using EBA infrastructure in public schools after the MoNE suspended schools due to COVID-19 pandemic. These problems can be listed as experiencing technical problems in live broadcasts, less class hours, unwillingness of teachers to conduct distance education, and that teachers are ineffective in watching and giving feedback to students. In this context, education cannot be continued in this way for a long time and 'new normal' need to be determined in the context of returning to school after the pandemic. School administrators have the opinion that after COVID-19 pandemic, things shall not be the same as before. Due to the importance of school, teacher and face-to-face education shall be realized again in the new normal.

Most of the school administrators stated that teachers were reluctant to teach in live lesson by using EBA education portal or other programs for various reasons. Hence, there was a gradual decrease in their motivation during the process in this study. During the pandemic process, teachers may be inexperienced about what online tools and resources they can use, which methods they can use, and they may need constant support. Without this support, a qualified process management cannot be possible (TEDMEM, 2020a). In the context of this study, school administrators stated that behind the decrease in the motivation of teachers for the educational process, there may be reasons such as low digital learning-teaching competencies, not having the necessary information technology tools, or not having a legal enforcement for not doing live lessons.

As a result of the study, the most common problems faced by school administrators during COVID-19 pandemic are, respectively, the inability to maintain students' motivation to learn, parents' inability to create a home learning environment for students, and the inability to access and connect live broadcasts from EBA TV/education portal. In the study conducted by Cao et al. (2020), it was observed that during the COVID-19 pandemic, anxiety level of one-quatre of university students increased and delays in academic activities were positively associated with anxiety symptoms. Studies (Brazendale, Beets, Weaver et al., 2017; Brooks, Webster, Smith, et al., 2020; Leung, Lam \& Cheng, 2020) show that when children are not attending school (for example, on weekends and summer holidays), they are less physically 
active, watch screens longer, sleep irregularly, and do not eat a balanced diet which causes weight gain. In the study by Sprang and Silman (2013), it was seen that children in quarantine had an average of four times higher stress scores than children who were not quarantined. A study conducted in Shaanxi Province, authorized by local authorities in the second week of February 2020, found out that the most common psychological and behavioral problems among 320 children and teens aged 3-18 were distraction, irritability, and fear of asking questions about the pandemic (Jiao et al., 2020). The interruption of education in schools has created anxiety, especially for students preparing for exams. In this context, students should be provided not only with academic support for the continuation of learning, but also psycho-social support (TEDMEM, 2020a). In the context of the results of this study, the uncertainty brought about by the pandemic and the uncontrolled learning process is likely to reduce the motivation of students to learn and study.

Due to the restrictions in social life, students can feel anxious, scared or have negative emotions during the pandemic (Özer, 2020). In the study conducted by Brazendale, Beets, Weaver et al. (2017), it was revealed that it is a critical factor for schools to create an interaction between students and teachers and to provide psychological guidance along with providing education materials and distance education for students during such pandemics. In this study, it was observed that although school administrators observed a decrease in students' learning motivation, they did not implement any practices to increase it.

The MoNE provided free internet right to parents' mobile lines for the use of EBA, but it was insufficient to announce this to parents. One-third of the parents were not aware of the content of the EBA application and they had these rights as a result of that. Another application that MoNE has failed to announce is the guidance and information broadcasts for parents on EBA TV. Half of the parents stated that they were not aware of the existence of the application, and only one-third of those who knew were completely satisfied (Yilmaz, Guner, Mutlu, \& Doganay, 2020). In this study, EBA TV and education portal application put into practice by the Ministry of National Education due to COVID-19 pandemic was evaluated positively by school administrators. School administrators stated that students' lack of having the opportunity to connect to computers and the internet, and parents' inability to support their children and to create learning comfort at home during this process have caused a decrease in the motivation of students. This may be due to the high expectations created by the MoNE about EBATV/education portal to meet all the learning needs of students.

It is seen that half of the school administrators made an emergency action plan and put it into practice when they encountered COVID-19 pandemic in this research. In particular, it is seen that distance education 
programs related to the implementation of live lessons from EBA were urgently put into use. This is alongside practices to ensure hygiene which was carried out quickly. It is also seen that half of the school administrators did not have an emergency action plan regarding the pandemic process and they mostly followed the instructions from the Ministry of National Education. It becomes even more important to take the necessary preventive and protective measures to create a healthy and safe education and training environment in schools, especially during the COVID-19 pandemic.

As a result of the research, school administrators revealed that technology leadership and crisis management skills are important needs in the pandemic process and that their competencies should be improved in these areas. In this context, characteristics and roles of good education, good school, ideal manager, and ideal teacher would change after the pandemic. It is predicted that in the near future, digital learning shall become the main basis of education beyond support or an alternative to face-to-face learning. Due to COVID-19 pandemic, digital learning would increase and become the main learning structure all over the world in the near future (Yamamoto \& Altun, 2020, p.33). Most especially in this process, it can be predicted that the function and mission of the school would change in 'the new normal' education order. The new normal of post-COVID-19 era offers an opportunity to rethink the goals of education (Cahapay, 2020). Within the new normal, the situation presents a unique challenge to every educational leader's decisionmaking process (Thapa, Sotang, Adhikari, Ghimire, Limbu, Joshi \& Adhikari, 2020). The Turkish education system should be prepared for the post-COVID19 era characterized by the 'new normal'. In this study, it is understood from the context of the statements of school administrators that schools would turn into center where face-to-face education is carried out (learning by doingliving, socialization, project-based work, etc.). In addition, e-learning is coordinated. In this process, as school administrators have stated, there would be a need to develop digital/technological leadership skills.

Based on the research, school administrators stated that within the scope of occupational health and safety, more attention should be paid to hygiene after the pandemic. In addition, it has been stated that when making emergency action plans, it is necessary to consider what to do against the epidemic.

With the interruption of education during COVID-19 pandemic, school administrators and teachers working in private education institutions were faced with many stress factors such as anxiety to support students, the possibility of being unemployed, increased expectations of parents from school, and financial concerns (TEDMEM, 2020b). As a result of the research, private school administrators stated that they realized that it is important to establish a financing balance (income-expenditure, debt balance) during the 
pandemic process. Furthermore, they opinioned that many private schools face the risk of closing down and not paying teachers' wages in this process.

With the emphasis on "COVID-19 Pandemic is the Litmus Test of Stakeholder Capitalism” (Schwab, 2020), the World Economic Forum stated that it is necessary to secure the job and personal rights of teachers working in official or private educational institutions and also to provide them with psycho-social support in this process. Planning of business administration, ensuring the continuity of employment, and the management and sustainability of school-parent relationships are vital for private education institutions. In this context, the legal regulation that prevents layoffs for three months in order to protect the employment of teachers working in private educational institutions in Turkey and to enable them get a salary is a positive practice.

In the context of the results of this study, the following recommendations can be presented:

- Contents of EBA TV/education portal that can support the access of millions of students and provide an important infrastructure should be enriched, and it should be inclusive for all students (special education, inclusive students, etc.). Deficiencies of EBA system should be identified and developed by considering COVID-19 pandemic as an opportunity and test. Synchronous lesson times in EBA can be kept longer for core lessons.

- More research regarding the online instructional replacements to faceto-face lessons and hybrid learning methods is needed.

- In the OECD (2020) report, it is suggested that the ministries of education of countries form a steering committee or scientific board for COVID-19 pandemic. In this process, it can be suggested that COVID-19 Pandemic Education Scientific Board consisting of members from academicians and bureaucrats with knowledge and experience should be founded.

- During the COVID-19 pandemic, it may be suggested to implement a school-based guidance system that will enable parents to support their children's learning process and to provide guidance in the context of creating learning comfort at home. Parents should be supported to be a part of the learning process and to play a role as the second teacher.

- Distance education support for inclusive and disabled students who need special education should be provided via EBA and parents should be supported in this regard.

- School administrators can be trained to develop digital/technology leadership and crisis management skills. 
- Private schools whose financial balances deteriorated during the pandemic period should be supported, and the job security and financial rights of the administrators and teachers working in these schools should be protected.

\section{References:}

1. Bilgin, N. (2006). Sosyal Bilimlerde İçerik Analizi: Teknikler ve Örnek Çalısmalar. 2. Bask1, Ankara: Siyasal Kitabevi.

2. Brazendale, K., Beets, M.W., Weaver, R.G., Pate, R. R., TurnerMcGrievy, G. M., Kaczynski, A. T., Chandler, J.L., Bohnert, A., \& von Hippel, P. T (2017). Understanding differences between summer vs. school obesogenic behaviors of children: The structured days hypothesis. International Journal of Behaviour Nutrition Physical Activity, vol. 14, p.100. https://doi.org/10.1186/s12966-017-0555-2

3. Brooks, S. K., Webster, R. K., Smith, L. E., Woodland, L., Wessely, S., Greenberg, N., \& Rubin, G. J. (2020). The psychological impact of quarantine and how to reduce it: Rapid review of the evidence. Lancet (London, England), $395 \quad$ (10227), 912-920. https://doi.org/10.1016/S0140-6736(20)30460-8

4. Cahapay, M. B. (2020). Rethinking Education in the New Normal Post-COVID-19 Era: A Curriculum Studies Perspective. Aquademia, 4(2), ep20018. https://doi.org/10.29333/aquademia/8315

5. Cao, W., Fanga, Z., Houc, G., Hana, M., Xua, X., Donga, J., \& Zhenga, J. (2020). The psychological impact of the COVID-19 epidemic on college students in China. Psychiatry Research, Vol. 287, 112934. https://doi.org/10.1016/j.psychres.2020.112934

6. Creswell, J. W. (2013). Research Design: Qualitative, Quantitative, and Mixed Methods Approaches. New York: Sage.

7. Creswell, J. W. (2017). Nitel Arastırmacılar için 30 Temel Beceri. Çev: Hasan Özcan. Anı Yayıncılık. Ankara.

8. Jiao, W. Y., Wang, L. N., Liu, J., Fang, S. F., Jiao, F. Y., Mantovani, M. P., \& Somekh, E. (2020). Behavioral and Emotional Disorders in Children during the COVID-19 Epidemic. European Paediatric Association, p.264-266. Retrieved on 12 June 2020 from https://www.jpeds.com/article/S0022-3476(20)30336-X/pdf

9. Leung, C. C., Lam, T. H., \& Cheng, K. K. (2020). Mass masking in the COVID-19 epidemic: people need guidance. The Lancet. Vol.395, No. 10228, p.945. https://doi/10.1016/s0140-6736(20)30520-1

10. Marshall, C. \& Rossman, G. B. (2014). Designing Qualitative Research. New York: Sage. 
11. Miles, M. B. \& Huberman, A. M. (1994). Qualitative Data Analysis: A Sourcebook of New Methods. 2nd Edition, Beverly Hills, CA: Sage Publications.

12. OECD (2020). A framework to guide an education response to the COVID-19 Pandemic of 2020. Paris: OECD Publishing.

13. Ozer, M. (2020). Vocational education and training as "a friend in need" during coronavirus pandemic in Turkey. Bartın University Journal of Faculty of Education, 9(2), 1-7.

14. Schwab, K. (2020). COVID-19 is a litmus test for stakeholder capitalism. World Economic Forum. Retrieved on 12 June 2020 from https://www.weforum.org/agenda/2020/03/covid-19-is-a-litmus-testfor-stakeholder-capitalism

15. Sprang, G. \& Silman, M. (2013). Posttraumatic stress disorder in parents and youth after healthrelated disasters. Disaster Medicine and Public Health Preparedness, Vol.7, p.105-110. https://doi.org/10.1017/dmp.2013.22

16. Thapa, S., Rai, N., Adhikari, J., Ghimire, A., Limbu, A. K., Joshi, A., \& Adhikari, S. (2020). Impact of COVID-19 Lockdown on Agriculture Education in Nepal: An Online survey. Pedagogical Research, 5(4), em0076. https://doi.org/10.29333/pr/8465

17. Tashakkori, A. \& Teddlie, C. (2010). Sage Handbook of Mixed Methods in Social \& Behavioral Research. 2nd Ed., Thousand Oaks, CA: Sage.

18. TEDMEM (2020a). COVID-19 Salgınında Ogrenmenin Surdurulmesi. Retrieved on 12 June 2020 from https://tedmem.org/covid-19/covid-19salgininda-ogrenmenin-surdurulmesi\#return-note-3280-1

19. TEDMEM (2020b). COVID-19 Salginı Surecinde Ogretmenler. Retrieved on 12 June 2020 from https://tedmem.org/covid-19/covid19-salgini-surecinde-ogretmenler

20. Tria, J.Z. (2020). The COVID-19 Pandemic through the Lens of Education in the Philippines: The New Normal. International Journal of Pedagogical Development and Lifelong Learning, 1(1), ep2001. https://doi.org/10.30935/ijpdl1/8311

21. UNESCO (2020). COVID-19 Educational Disruption and Response. $\begin{array}{lllll}\text { Retrieved on } & 12 & \text { June } & 2020 & \text { from }\end{array}$ https://en.unesco.org/covid19/educationresponse

22. Ustun, C. \& Ozciftci, S. (2020). Effects of COVID-19 Pandemic on Social Life and Ethical Plane: An Evaluation Study. Anatolian Clinic Journal of Medical Sciences, Vol. 25, Special Issue 1. https://doi.org/10.21673/anadoluklin.721864 
23. Viner, R.M., Russell, S. J., Croker, H., Packer, J., Ward, J., Stansfield, C., Mytton, O., Bonell, C., \& Booy, R. (2020). School closure and management practices during coronavirus outbreaks including COVID-19: A rapid systematic review. Lancet Child Adolesc Health, Vol. 4., No. 4, p. 397-404. https://doi.org/10.1016/S23524642(20)30095-X

24. World Health Organization (WHO) (2020). Director-General's remarks at the media briefing on 2019- nCoV on 11 February 2020. Retrieved on 12 June 2020 from https://www.who.int/dg/speeches/detail/who-director-general-sremarks-at-themedia-briefing-on-2019-ncov-on-11-february-2020

25. Yamamoto, G. T. \& Altun, D. (2020). The Coronavirus and the Rising of Online Education. Journal of University Research, Volume 3, Issue 1, Page: 25-34.

26. Yildırım, A. \& Simsek, H. (2018). Sosyal Bilimlerde Nitel Arastırma Yontemleri. 11. Bask1., Ankara: Seckin Yayıncılık.

27. Yilmaz, E., Guner, B., Mutlu H., \& Doganay. (2020). Veli Algisina Gore Pandemi Donemi Uzaktan Egitim Surecinin Niteligi. Konya: Palet yayinları. 